\title{
EVALUATING THE ROLL OF SERVICE QUALITY AS A MEDIATOR ON USER SATISFACTION IN E- GOVERNMENT APPLICATIONS
}

\author{
Mohammed A. Kafaji \\ Alfaisal University, Riyadh, Kingdom of Saudi Arabia \\ E-mail: mkafaji@alfaisal.edu
}

\begin{abstract}
This study is designed to assess the mediating effect of the Service Quality in shaping the experience of users of e-Government applications. Users normally evaluate their satisfaction in using technological innovation such as e-Government from their direct and indirect involvement and the perceived value of the system in question. To study the mediation effect, a self-administered questionnaire based on a tested model is used to collect the experience of users of recently implemented e-Government applications in the public sector in Saudi Arabia. Data was gathered from 208 internal respondents and then analyzed using structural equation modeling (SEM). Different mediation models were tested and evaluated using common standard SEM parameters. The results showed that the value perceived from the System Quality and Information Quality does impact the User Satisfaction, but Service Quality was found to play a stronger role in mediating the relationship between User Satisfaction and both the System Quality and Information Quality. The degree and direction of this mediation were analyzed and interpreted from the user and the technical support perspectives. The study compares these findings with those from earlier studies using similar models.
\end{abstract}

Key words: e-government, mediation, structural equations modeling, information quality, system quality, service quality, user satisfaction.

\section{Introduction}

With high demands at increased functionality of citizens to utilize advanced technologies, many governments around the world are under pressure to provide advanced and customized services to its citizens through online applications. Thus many local governments have turned to information and communication technologies (ICT) to achieve this objective (Chen 2003). Although the achievement of such an objective is a challenge by itself, but ensuring that the offered services contribute to improved e-Government operational effectiveness and efficiency adds extra complexity (Gil-Garcia and Pardo, 2005; Yildiz, 2007). However, implementation of information systems in general is a challenging exercise experienced by all organizations taking such an initiative (Yildiz, 2007). The e-Government information systems are not exception as the implementation still facing many difficulties, which in many cases resulted to project failures (Goldfinch 2007). Much research conducted to analyze underpinning causes of these failures; some studies attribute the failures to lack of provision of required resources for successful implementation such as financial, infrastructure, and legalizations from the central government, (Al-Saber et al., 2007; Shackleton and Dawson, 2007; Mofleh et al.,2009). Others associated failure in e-Government implementation projects to not considering and integrating end users throughout the implementation process (Verdegem and Verleye 2009; Gauld et al., 2010). 
PROBLEMS

OF MANAGEMENT

IN THE $21^{\text {st }}$ CENTURY Volume 8, 2013

56

Furthermore, as e-Governmental services become an essential part of modern interaction between local governments and citizens, the quality of offered services has taken an essential driving role in implementing e-Government systems (Naz 2009). Thus many public organizations have taken this matter seriously and turned to innovation in information technology to offer variety of e-services at improved level of service quality (Chen 2003). The underpinning cause of this change in attention is the perceived anxiety on the quality of the offered services by the public sector (Halaris et al. 2007). To cater for this matter, much work has been published on the quality of offered services of e-Government applications (Santos, 2003, Lee \& Lin 2005, Papadomichelaki et al. 2006, Hongxiu \& Reima 2009). From this brief introduction, there is a need to evaluate how the quality of offered service in e-Government applications impacts User Satisfaction; which is a key topic of this study. Therefore, many studies highlighted the importance of considering both qualities of offered services as well the satisfaction of end users in managing the implementation of e-Government systems. Generally speaking, in developing countries and due to lack of local resources and experience, the local governments have turned to international consultancy services to assist them with the implementation of enterprise systems such as e-Government applications. Although such approach is acceptable practice, but due to time constraints and focus on executive needs, the end user requirement might be overlooked. Technology in the Middle-East is widely accepted with internet penetration rate higher than the rest of the world (Al-Kouri 2013). This can be considered as an enabling success factor for successful implementing e-Government related applications with ability to reach and serve wider and remote communities (Bhatnagar, 2004). In the Kingdom of Saudi Arabia, various researches on e-Government were conducted focusing on different e-Government aspects (see for example El-Sofany et al 2012, Almalki, et al. 2013), but little work was published on the role of quality of service in effecting the User Satisfaction of e-Government systems.

From above introduction, one aspect of this study is to analyze the impact of quality of offered services on the level of internal User Satisfaction in e-Government applications in some public sector organization in Saudi Arabia. Therefore, the main research question to be answered is: "To what extend the integration of Service Quality in the e-Government implementation plans will improve the level of User Satisfaction?" However at this stage, the user within the context of this work refers to the 'internal users', i.e. the management and support personnel within a public organization that are involved in facilitating the provision of e-Government services to the public citizens and services.

\section{Problem of Research}

This work is attempting to answer the following questions:

1. Does the quality of the e-Government systems influence the User Satisfaction?

2. Does the quality of the e-Government information influence the User Satisfaction?

3. Do the System Quality and Information Quality mutually influence each other?

4. Does the Service Quality offered by the e-Government support personnel mediate the relationship between System Quality and User Satisfaction?

5. Does the Service Quality offered by the e-Government systems mediate the relationship between Information Quality and User Satisfaction?

\section{Research Focus}

In conducting this research, the structural equation models and related approaches are utilized to study whether System Quality and/or Information Quality of the e-Government systems affect the level of User Satisfaction in some organizations of the public sector in Saudi Arabia. The research related quantitative data were gathered through a self-administered questionnaire directed to large service organizations in the public sector in Saudi Arabia which had recently implemented e-Government systems. 


\section{Methodology of Research}

General Background of Research

Four key constructs are commonly used to measure the success or effectiveness of information systems (DeLone and McLean 1992, 2003, Nielsen 2005, Petter et.al, 2013, Jingjun et al. 2013). Based on this model and studies, the definitions of constructs used in this study are:

System Quality: defined as a measure of technical efficacy, i.e. the desired characteristics of the system. It is measured in terms of ease-of-use, functionality, reliability, flexibility, data quality, portability, integration, and importance.

Information Quality: defined as the measurement of output from enterprise information systems. It is measured in terms of accuracy, timeliness, completeness, relevance, and consistency.

Service Quality: defined as the level of service received by the users of enterprise information systems and the manner in which the service is provided by the IS/IT department. It influences the degree of satisfaction with an enterprise information system and thus expected that training, support and online help are factors will impact the relationship between IS/IT support services and the system users (Pitt et al., 1995).

User Satisfaction: defined as the extent at which an information system (e-Government in this case) creates values to help internal users achieving expected level of satisfaction to improve their own job related performance measures.

\section{Sample of Research}

Five hundred (500) surveys were distributed to selected government organizations that had recently implemented e-Government systems. The respondents only returned 208 surveys, i.e. a $45.6 \%$ response rate. Each returned questionnaire was reviewed for completeness and, of the 208, eight were considered unusable due to large amounts of missing data, lack of involvement of the respondent in the use of e-Government system, or the impossibility of identifying the role of the respondent (manager, engineer or operator-user). Furthermore in order to improve the quality of the collected data, another 18 returned surveys were rejected due to missing data and due to 'disengaged' respondents, i.e. respondents that tend to select one or two answers on the point-scale questions.

\section{Instrument and Procedures}

As stated by Orlikowski \& Gash (1994) and Schein (1996), different workers in an organization have different assumptions, expectations, knowledge and perceptions of technological innovation. Thus, the questionnaire used in this study was administered to managers, engineers (technologists), and administrative and operational staff to gather data related to various aspects of usage of enterprise information system. For this purpose, twenty five questions were selected from a pool of thirty two (32) questions compiled from three previous studies mentioned in the DeLone and McLean (2003). This questionnaire was previously used to study and evaluate various performance dimensions to assess operational effectiveness (Santa et al., 2009).

A five-point Likert scale was used with 1 represents a 'Strongly Disagree' response and 5 represents 'Strongly Agree' response. The workers were consulted before administering the surveys and they expressed willingness to take part in this study. Since this research is specifically designed to assess the effect of system and information on the internal User Satisfaction, the workers were selected from different roles and positions. In this way the gathered data is directly related to the topic of this research and collected from professionals with relevant and adequate hands-on experience and knowledge. 
PROBLEMS

OF MANAGEMENT

IN THE $21^{\text {st }}$ CENTURY Volume 8, 2013

58

In this study it is proposed that the quality of computer applications and quality of the produced information from e-Government systems have direct effect on the User Satisfaction. The users in the context of the present study are those involved in the actual usage of the systems for operational purposes. More questions were used to assess whether the Service Quality plays a role in mediating the relationship between the System Quality \& Information Quality on one hand and the User Satisfaction on the other.

\section{Data Analysis}

The 'System Quality' and 'Information Quality' are selected as exogenous variables and the 'Service Quality' and 'User Satisfaction' are the endogenous variables. Such models are often used for studying the operational effectiveness of information systems. The relationship between these constructs was the target of many studies; see for example DeLone \& McLean 1992, 2003; Nielsen 2005, Petter et.al, 2013, Jingjun et al. 2013.

The gathered data were analysed using a multivariate statistical which combines path analysis with Confirmatory Factor Analysis (Hair et al. 2010). The SPSS application (version 21.0), with AMOS add-on was used to construct the Structural Equation Model (SEM), is used to test the relationships depicted in the proposed casual model (see figure 1 below). These applications are used to study how and to what extent the selected exogenous variables affect the 'User Satisfaction' in a direct relationship and indirectly through the mediating construct 'Service Quality'. Errors were considered by adding error parameters to each variable which is a standard approach to manage error (Hair et al. 2010).

For the mediation aspect of this study, the Service Quality is considered as the mediator between two independent variables: System Quality \& Service Quality and the dependent variable: User Satisfaction. The approach adopted in this research started by first qualifying the raw data gathered through the questionnaire. This was done by removing partially filled cases (through identification of missing data), then removing cases of 'disengaged users' through calculating the standard deviation of each case and remove those cases with standard deviation below 0.6. Then Confirmatory Factor Analysis (CFA) was used to extract necessary factors required to identify the underlying data structure of gathered data set (Hair et al. 2010). In order to evaluate data reliability, the internal consistency measures (Cronbach's $\alpha$ ) were calculated for every extracted factor.

The output of these steps is shown in table 1, together with other supporting description statistical measurements. The value of Kaiser-Meyer-Olkin (KMO) is 0.913 (with $\mathrm{p}<0.001$ ) indicating the appropriateness of factor analysis with adequate sampling (Tabachnick \& Fidell 2007). 
Table 1. Confirmatory Factor Analysis showing: Selected Factors, Data Reliability (Cronbach's a), Factor Items, Factor Loadings $(\beta)$, Critical Ratio (CR), Standard Errors (SE), and Significance Level (P).

\begin{tabular}{|c|c|c|c|c|c|c|c|}
\hline Selected Factors & Cronbach's $\alpha$ & Items & Mean & $\beta$ & CR & SE & $\mathbf{P}$ \\
\hline \multirow{3}{*}{ System Quality } & \multirow{3}{*}{0.879} & SQ1 & 3.50 & 0.962 & -- & -- & \\
\hline & & SQ2 & 3.52 & 0.889 & 19.643 & 0.047 & $* * *$ \\
\hline & & SQ3 & 3.75 & 0.698 & 12.291 & 0.054 & $* * *$ \\
\hline \multirow{5}{*}{ Information Quality } & \multirow{5}{*}{0.876} & IQ1 & 3.37 & 0.787 & -- & -- & \\
\hline & & IQ2 & 3.46 & 0.840 & 12.204 & 0.094 & $* * *$ \\
\hline & & IQ3 & 3.49 & 0.736 & 12.765 & 0.075 & $* * \star$ \\
\hline & & IQ4 & 3.39 & 0.761 & 10.654 & 0.101 & $* * *$ \\
\hline & & IQ5 & 3.52 & 0.669 & 9.327 & 0.085 & $* * *$ \\
\hline \multirow{5}{*}{ Service Quality } & \multirow{5}{*}{0.832} & SRQ1 & 3.54 & 0.744 & -- & -- & \\
\hline & & SRQ2 & 3.34 & 0.615 & 10.344 & 0.086 & $* * *$ \\
\hline & & SRQ3 & 3.57 & 0.610 & 8.44 & 0.097 & $* * *$ \\
\hline & & SRQ4 & 3.38 & 0.659 & 8.536 & 0.118 & $* * *$ \\
\hline & & SRQ5 & 3.32 & 0.732 & 9.287 & 0.121 & $* * *$ \\
\hline \multirow{4}{*}{ User Satisfaction } & \multirow{4}{*}{0.792} & US1 & 3.67 & 0.635 & -- & -- & \\
\hline & & US2 & 3.59 & 0.747 & 9.86 & 0.118 & $* * \star$ \\
\hline & & US3 & 3.62 & 0.751 & 7.861 & 0.152 & $* * *$ \\
\hline & & US4 & 3.28 & 0.626 & 6.625 & 0.163 & $* * *$ \\
\hline
\end{tabular}

A total of four factors were extracted that explained a total variance of $58 \%$ and all factor loadings are more than 0.6 which are accepted (Matsunag 2010). The constructs' reliability factors (Cronbach's $\alpha$ ) exceeded the recommended standard 0.7 value (Hair et al 2006). These calculations indicate the suitability and reliability of the data used for conducting the Factor Analysis.

The next step is using SEM technique to examine the structural relationships among the four selected constructs: System Quality, Information Quality, Service Quality, and User Satisfaction. The selection of SEM to investigate the factor analysis results facilitates simultaneous test of both the structural model between the latent variables and the measurement model between the constructs (Kline 2005). For this purpose, two conceptual models are proposed, as shown in figures 1. In (a) the relationship between System Quality, Information Quality, and Ussr Satisfaction were quantified and analyzed. Then the same model was reassessed with 'Service Quality' added as a mediator as shown in figure $1 \mathrm{~b}$. The approach to evaluate mediation in this way is often suggested and report in the literature (see for example, Joseph et al 2010). 
PROBLEMS

OF MANAGEMENT

IN THE $21^{\text {st }}$ CENTURY Volume 8,2013

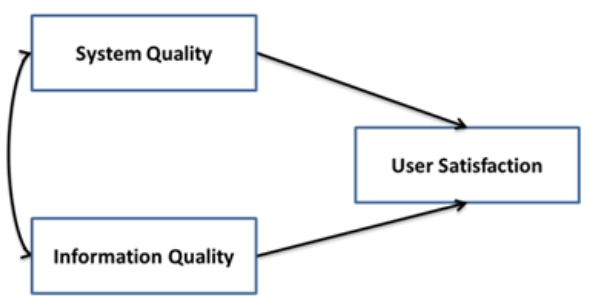

(a)

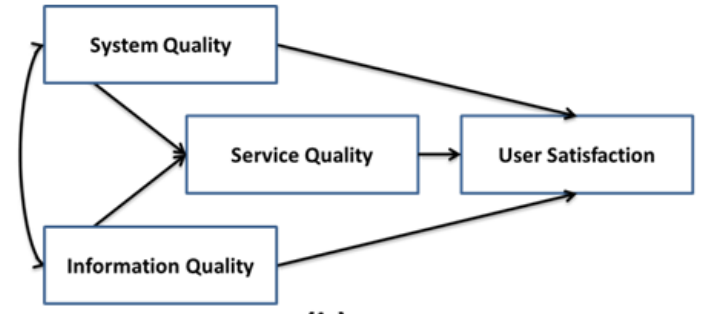

(b)

Figure 1. Conceptual path diagrams of models simulating the effect of "System Quality", "Information Quality" and "Service Quality", on "User Satisfaction" for internal user of e-Government systems; (a) without mediating effect and (b) with "Service Quality" as the mediating variable.

\section{Results of Research}

Before proceeding with the interpretation of the mediating data for the proposed models in figure 1, the goodness-of-fitness of the two models was evaluated using Confirmatory Factor Analysis (Cooksey, 2007; Hair et al., 2010). The chi-square and goodness-of-fit statistics are listed in table 2.

Table 2. Measurements of Model Goodness-of-Fit Parameters.

\begin{tabular}{lcccccccccc}
\hline Model & $\chi^{2}$ & DF & $\mathbf{p}$ & $\chi^{2} /$ DF & RMSEA & GFI & CFI & NFI & IFI & TLI \\
\hline $\begin{array}{l}\text { Model A (not medi- } \\
\text { ated) }\end{array}$ & 92.605 & 48 & $* * *$ & 1.929 & 0.070 & 0.924 & 0.966 & 0.934 & 0.967 & 0.954 \\
\hline $\begin{array}{l}\text { Model B (with } \\
\text { mediation) }\end{array}$ & 194.610 & 107 & $* * *$ & 1.819 & 0.066 & 0.894 & 0.953 & 0.904 & 0.954 & 0.941
\end{tabular}

Note: Number of stars indicate the level of significance; ${ }^{*}=0.05,{ }^{* *}=0.01$, and ${ }^{* * *}<0.001$

As can be seen from the table 2, for both models $\mathrm{A}$ and $\mathrm{B}$, the ratio of chi-square to the degree of freedom $(\chi 2 / \mathrm{DF}$ ) is 1.929 (with $\mathrm{N}=200, \mathrm{DF}=48$ ) and 1.819 (with $\mathrm{N}=200, \mathrm{DF}=107$ ) respectively. These values are acceptable and below the threshold value and thus indicate good fit (Bollen 1989; Kline 2005). Furthermore, additional goodness-of-fit parameters of GFI (goodness-of-fit index), CFI (comparative fit index), NFI (Normal Fit Index), IFT (Incremental Fit Index), and TLI (Tucker-Lewis Index) are all over the minimum threshold of 0.9 (except for the GFI of model B) and less than 1.0 which again support that both prosed models do fit the research data. Finally, these findings are further supported by RESEA (root mean square error of approximation) value less than the recommended value of 0.08 (Browne \& Cudeck, 1993, Hair et al., 1995, Hu \& Bentler, 1999). All this data support each other and indicate that the hypothesized model fits the observed variance-covariance matrix well relative to null or independence model.

The next actions are to examine the proposed two models shown in figure 1. First the direct effect of the relationships between System Quality, Information Quality, and User Satisfaction without mediation were examined (Holmbeck 1997). The results are shown in figure 2. 


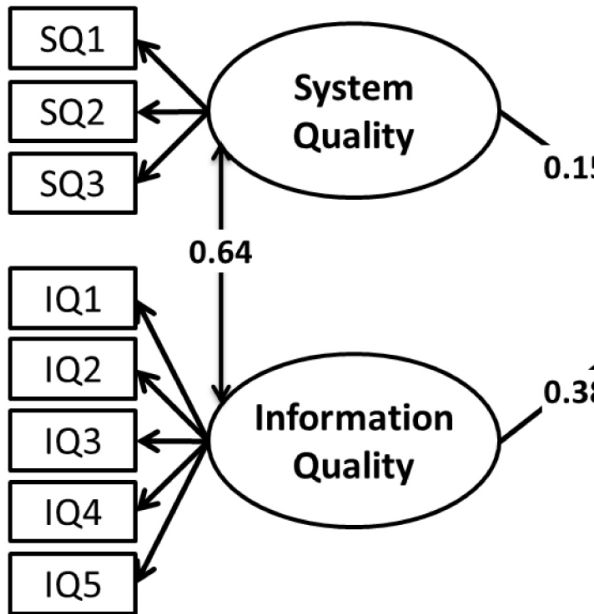

Figure 2. Results of testing the structural model shown in figure 1a. The relevant statists is shown in table 2.

Figure 2 together with quantitative statistical data shown in table 2 indicate a good model fit with RMSEA less than 0.8 and CFI grated than 0.95 (Hu and Bentler 1999). Although weak, the data indicates that System Quality has positive correlation with the User Satisfaction with path weight of 0.15 and significant $(\mathrm{P}<0.001)$. Similarly, the path coefficients between 'Information Quality' and 'User Satisfaction' is 0.38 and between 'Information Quality' and 'System Quality' is 0.64 . All these path coefficients are significant with $\mathrm{P}<0.001$. Although to different extends, this data answer the first three queries stated earlier. Thus the research can be further advanced to study the mediation effect.

The results stated above satisfy the first requirement to apply the mediation concept, i.e. having a significant correlation to be mediated (Holmbeck 1997). First the partial mediation of Service Quality on (a) the effect of System Quality on User Satisfaction and (b) the effect of In-

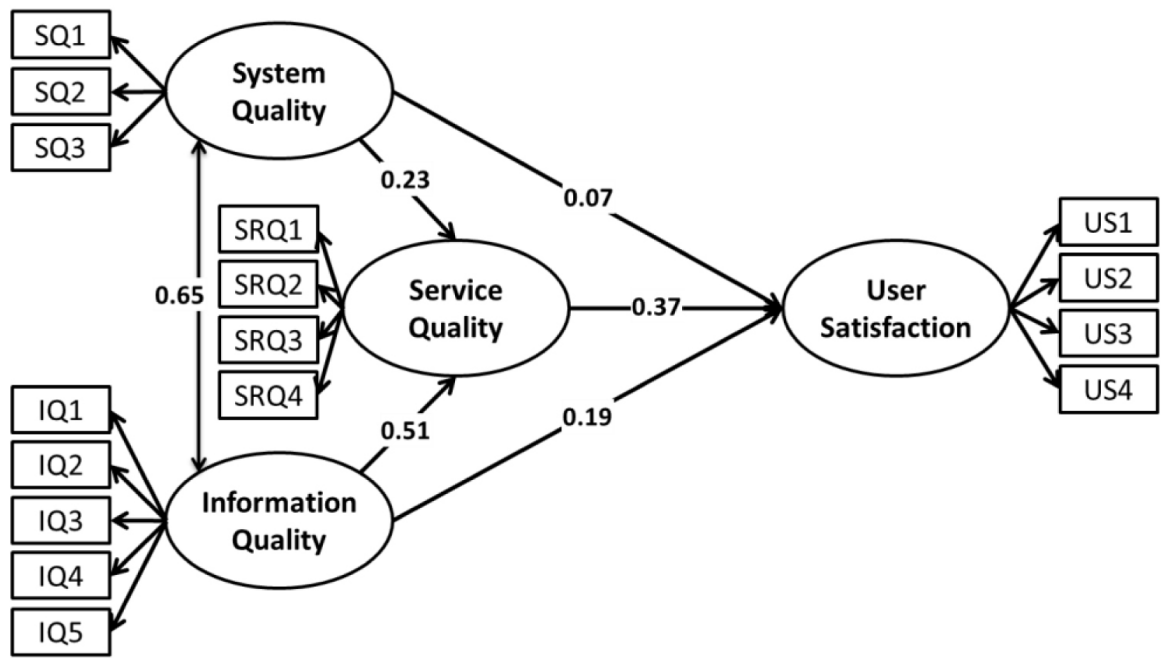

formation Quality on User Satisfaction were studied. The full structural model for this analysis is shown in figure 3 .

Figure 3. Results of testing the structural model shown in figure $\mathbf{1 b}$. The relevant statists is shown in table 2. 
PROBLEMS

OF MANAGEMENT

IN THE $21^{\text {st }}$ CENTURY

Volume 8,2013

Figure 3, shows that System Quality and Information Quality are significantly associated with the Service Quality (path coefficients are 0.23 and 0.51 respectively with $p<0.001$ in both). Furthermore, the Service Quality is significantly associated with the User Satisfaction with a path coefficient of 0.37 and $\mathrm{P}<0.02$. However, the path coefficient between the System Quality and User Satisfaction is now reduced and become not significant. In addition, the path coefficient between Information Quality and User satisfaction was also reduced and become not significant. This data is summarized in Table 3 which also answers research questions 4 and 5 stating that the quality of offered services associated with e-Government systems plays important role in determining the level of User Satisfaction.

Table 3. Comparison of path coefficients with and without mediation.

\begin{tabular}{lllll}
\cline { 2 - 4 } & Without Mediation & \multicolumn{2}{l}{ With Mediation } \\
\hline Path & Path Coefficient & $P$ & Path Coefficient & $P$ \\
\hline System Quality > User Satisfaction & 0.306 & 0.004 & 0.135 & 0.256 \\
\hline Information Quality > User Satisfaction & 0.529 & $* * *$ & 0.264 & 0.106 \\
\hline
\end{tabular}

\section{Discussion}

This research starts by attempting to study the relationship between System Quality, Information Quality, and User Satisfaction. The study then moves further to examine the mediation effect of the Service Quality offered by the e-Government systems on the these relationships. The main expected outcome of this study is to evaluate whether Service Quality play important role in determining the level of User Satisfaction and the extent of this role. Despite extensive research activities on the User Satisfaction areas, but only few researchers studied these concepts within the e-Government in public sectors contexts. Generally speaking, in implementing e-Government systems, the vendors and consultancy companies often focus on the functional aspects only. This is particularly visible in developing countries where the implementation normally is performed by specialized consultants for different countries, culture, and backgrounds. Therefore, their mission is to deliver the scope of work by satisfying and demonstrating expected technical and functional system capabilities to project owners and executive management who will sign the acceptance documents. Once project functional objectives are met and a signed-off, then the project is classified as success. However, from operational perspective, the appropriate assessment of system implementation would focus on how the systems achieve the expected operational effectiveness for the whole organization. In other words, to what degree the e-Government systems are able to establish processes, based on core capabilities within the organization that encourage them to exceed customer's expectations (Porter, 1996; Evans and Lindsay, 2011) and use these accomplishments to achieve organizational goals and benefits (DeLone and McLean 1992, 2003). One critical aspect of these expectations is the users' satisfaction level, which was analyzed in this study from the perspective of relationship with System Quality and Information Quality.

The mediation test indicates that Service Quality has stronger effect on User Satisfaction with high values of the correlation coefficients. This also can be seen through partially mediating (almost total mediation) the relationship between System Quality and User Satisfaction. This in turns explains the moderately low direct effect (without mediation) of System Quality on the User Satisfaction. Furthermore, the Service Quality partially meditates between the In- 
formation Quality and User Satisfaction. These results answered the questions on the affect of System Quality and Information Quality on User Satisfaction, which turned to be positive and consistent with earlier reported observations (DeLone and McLean 2003). However, this study showed that Service Quality plays rather stronger role in affecting the User Satisfaction, which made the effect of System Quality on User Satisfaction secondary. One potential explanation of these observations is that system users are evaluating the e-Government systems through their personal experience with the support services provided by the IT services personnel rather than the actual System Quality or Information Quality which are, for technical reasons, are shielded away from the end user.

To extent this research further, the mediation roles of Service Quality can be further applied to the relationship between the Service Quality \& Information Quality of e-Government systems and the End-Users Satisfaction (the public). Since the End-Users are completely 'shielded' from the actual back-end of the e-Government systems, then it would be interesting to compare the degree and direction of mediation of Service Quality on User Satisfaction (internal users) and End-User Satisfactions (external users).

\section{Conclusions}

With increased pressure on public organizations to provide effective and efficient services to the citizens and businesses, many public organizations invested heavily in implementing e-Government systems. Naturally, a key objective in such initiatives is to serve the end-users, and thus user considerations and involvements must play an important success factor in project management. However, in post-implementation, many e-Government projects suffered from technical as well-as operational difficulties, which on one aspect, can be attributed to excluding user involvements and in the implementation lifecycle. Therefore, it is important for the sponsoring organizations to understand the factors that impact the level of User Satisfaction and how improved implementation planning can help to improve satisfaction level. This study is attempting to analyze the role of support services offered by technical support personnel to improve the level of User Satisfactions with the final product.

The study showed that the User Satisfaction of e-Government applications in day-to-day operations is partially mediated by the perceived Service Quality offered by the e-Government systems through the IT Service personnel. This mediation is taking place between User Satisfaction and both the System Quality and the Information Quality. Although it is assumed that high System Quality results in increased User Satisfaction, but this results seem to support that Service Quality play stronger role in impacting the level of attained User Satisfaction. Generally speaking, in implementing complex systems such as e-Government by an external consultancy firm, the focus is normally on satisfying project owners through demonstration of achieving system functional capabilities. Although System Quality and Information Quality play important roles in User Satisfaction, the current study indicated that the integration of Service Quality during pre- and post-implementation phases of e-Government systems plays crucial roles in meeting user expectations. These results support that user-driven implementation has better chances to achieve targeted organizational performance objectives. The study also suggests that public organizations need to provide tailored IT Services specifically in the post-implementation stage to attain acceptable level of User Satisfaction. Furthermore, the study also suggests the needs for careful integration of key stakeholders from the IT Support Services into the full life cycle of e-Government implementation and pre-planned and customized training programs can help increase the level of User Satisfaction. This in turns helps the organization take best 
Mohammed A. KAFAJI. Evaluating the Roll of Service Quality as a Mediator on User Satisfaction in E-government Applications

PROBLEMS

OF MANAGEMENT

IN THE $21^{\text {st }}$ CENTURY

Volume 8, 2013

64 advantage of the investment and thus the targeted organizational objectives.

\section{References}

Al-Khouri, A. M. (2013). e-Government in Arab Countries: A 6-Staged Roadmap to Develop the Public Sector. Journal of Management and Strategy, 4 (1), 80-107.

Almalki, O., Duan, Y., \& Frommholz, I. (2013). Developing a Conceptual Framework to Evaluate eGovernment Portals' Success. Proceedings of the European Conference on e-Government.

Al-Saber, S., Hossain K., \& Srivastava A. (2007). Technology, Society and E-government: In Search of an Eclectic Framework. International Journal of Electronic Government, 4 (2), 156-178.

Bhatnagar, S. (2004). E-government: From Vision to Implementation: A Practical Guide with Case Studies. India: Sage Publications.

Bollen, K. A. (1989). Structural equations with latent variables. New York: Wiley.

Browne, M. W., \& Cudeck, R. (1993). Alternative Ways of Assessing Model Fit. In K. A. Bollen \& J. S. Long (Eds.), Testing structural equation models. Newbury Park, CA: Sage.

Halaris C., Magoutas, B., Papadomichelaki, X., \& Mentzas G. (2007). Classification and synthesis of quality approaches in e-Government services. Internet Research, 17 (4), 378-401.

Cooksey, R. (2007). Illustrating statistical procedures for business, behavioural \& social science research. Australia: Tilde University Press.

DeLone, W., \& McLean, E. (1992). Information systems success: The quest for the dependent variable, Information Systems Research, 3 (1), 60-95.

DeLone, W., \& McLean, E. (2003). The DeLone and McLean model of information system success: A ten-year update. Journal of Management Information Systems, 19 (4), 9-30.

El-Sofany, H. F., Al-Tourki, T., Al-Howimel, H., \& Al-Sadoon, A. (2012). E-government in Saudi Arabia: Barriers, Challenges and its Role of Development. International Journal of Computer Applications, 48, 16-22.

Evans, J., \& Lindsay, W. (2011). The Management and Control of Quality. New Jersey: South-Western Cengage Learning.

Gauld, R., Goldfinch, S., \& Horsburgh, S. (2010). Do They Want It? Do They Use It? The Demand Side of E-Government in Australia and New Zealand. Government Information Quarterly, 27 (2), $177-86$.

Lee G. G., \& Lin, H. F. (2005). Customer perceptions of e-service quality in online shopping. International Journal of Retail \& Distribution Management, 33 (2), 161-176.

Gil-Garcia, J. R., \& Pardo, T. A. (2005). E-government Success Factors: Mapping Practical Tools to Theoretical Foundations. Government Information Quarterly, 22 (2), 187-216.

Goldfinch, S. (2007). Pessimism, Computer Failure, and Information Systems Development in the Public Sector. Public Administration Review, 67 (5), 917-929.

Chen, H. (2003). Digital government: Technologies and practices. Decision Support Systems, 34 (3), 223-227.

Hair J., Anderson, R. E., Tatham, R. L., \& Black, W. C. (1995). Multivariate data analysis. 4th Ed. New Jersey: Prentice-Hall Inc.

Hair, J. F., Black, W. C., Babin, B. J., Anderson, R. E. (2010). Multivariate Data Analysis: International Version, 7th Ed, New Jersey: Pearson.

Hair, J. F., Black, W. C., Babin, B. J., Anderson, R. E., \& Tatham, R. L. (2006). Multivariate data analysis (6th Ed.). Upper Saddle River, NJ: Prentice Hall.

Holmbeck, G. N. (1997). Toward terminological, conceptual, and statistical clarity in the study of mediators and moderators: Examples from the child-clinical and pediatric psychology literature. Journal of Counseling and Clinical Psychology, 65 (4), 599-610.

Hu, L.T., \& Bentler, P. M. (1999). Cutoff criteria for fit indexes in covariance structure analysis: Conventional criteria versus new alternatives. Structural Equation Modeling, 6 (1), 1-55.

Santos, J. (2003). E-service quality - a model of virtual service dimensions. Managing Service Quality, 13 (3), 233-247.

Jingjun, X., Benbasat, I., \& Cenfetelli, R. T. (2013). Integrating Service Quality with System and Information Quality: An Empirical Test in the e-Service Context. MIS Quarterly, 37 (3), 777-A9.

Kline, R. B. (2005). Principles and practice of structural equation modeling (2nd ed.). New York: The Guilford Press.

Hongxiu, L., \& Reima, S. (2009). A Proposed Scale for Measuring E-service Quality. International Journal of $u$ - and e-Service, Science and Technology, 2 (1), 1-10. 
Matsunaga, M., (2010). How to Factor-Analyze Your Data Right: Do’s, Don’ts, and How-To's. International Journal of Psychological Research, 3 (1), 97-110.

Mofleh, S., Wanous M., \& Strachan P. (2009). Understanding National E-government: The Role of Central Government. International Journal Electronic Government, 6 (1), 1-18.

Naz, R., (2009). E-governance for Improved Service Delivery in Fiji. Journal of Service Science and Management, 2 (3), 190-203.

Nielsen, J. (2005). Critical success factors for implementing ERP system. In L. Von Hellens, S Nielsenand, J. Beekhuyzen (Eds), Qualitative Case Studies on Implementation of Enterprise Wide Systems (211-231). London: Idea Group Inc.

Petter, S., DeLone, W., \& McLean, E. (2013). Information Systems Success: The Quest for the Independent Variables. Journal of Management Information Systems, 29 (4), 7-62.

Porter, M. (1996). What is strategy? Harvard Business Review, 74 (6), 61-78.

Santa, R., Ferrer, M., Bretherton, P., \& Hyland, P. (2009). The necessary alignment between technology innovation effectiveness and operational effectiveness. Journal of Management and Organisation, 15 (2), 155-169.

Shackleton, P., Fisher, J., \& Dawson, L. (2004). Evolution of Local Government E-Services: The applicability of e-business Maturity models. In: Proceedings of the 37th Hawaii International Conference on System Sciences. Hawaii.

Tabachnick, B. G., \& Fidell, L. S. (2007). Using multivariate statistics (5th Ed.). Boston: Pearson Education.

Verdegem, P., \& Verleye, G. (2009). User-Centered E-Government in Practice: A Comprehensive Model for Measuring User Satisfaction. Government Information Quarterly, 26 (5), 487-97.

Xenia Papadomichelaki, X., Magoutas, B., Halaris, C., Apostolou, D., \& Mentzas, G. (2006). A review of quality dimensions in e-Government services. Proceedings of the 5 th international conference on Electronic Government (EGOV'060), 128-138, Springer-Verlag.

Yildiz, M. (2007). E-government research: reviewing the literature, limitations, and ways forward. Government Information Quarterly, 24 (3), 646-665.

Advised by Nikhil Chandra Shil, American International University, Dhaka, Bangladesh

Received: October 06, 2013

Accepted: November 28, 2013

Mohammed A. Kafaji

PhD, Assistant Professor, College of Business, Alfaisal University, P.O. Box 50927, Riyadh 11533, Kingdom of Saudi Arabia.

E-mail: mkafaji@alfaisal.edu

Website: http://www.alfaisal.edu 